\title{
INSTITUTE OF COURT INTERPRETERS IN THE ENGLISH-SPEAKING COUNTRIES: STRENGTHS AND WEAKNESSES
}

\author{
Valentina V. Stepanova \\ PhD, Associate Professor ,6 Mikluho-Maklaya str. Department of foreign languages, Law Institute \\ Peoples' Friendship University of Russia (RUDN University), Moscow 117198 Russia E-mail: \\ valentina0222@mail.ru
}

\begin{abstract}
Profession of a court interpreter is gaining great demand all over the world due to numerous social tendencies, including migration, labour migration, tourism, and cross-border movements for other purposes. Offences committed by such aliens in the host countries as well as foreign-born citizens strain court systems as the offenders most often do not comprehend the language of the proceedings. The legal systems regulate this sphere with a well-developed rules concerning engagement of interpreters into this activity; moreover the formed institutes of court interpreters heavily contribute to this end. The article looks at such experiences and studies strengths and weaknesses of court interpreting services in a number of English-speaking countries (U.S.A, Canada and Australia). The methods of synthesis and analysis, comparative and contrasting techniques as well as deductive reasoning comprise the methodology of the study. The article is the second approach to a more comprehensive topic of specifics of interpreter's engagement in criminal proceedings in a number of national jurisdictions.
\end{abstract}

Keywords: Institute of court interpreters, certification of court interpreters, fees of court interpreters, testing of court interpreters

\section{INTRODUCTION}

Interpreters and translators are inalienable members of court proceedings where some of the participants do not understand and/or speak the language of the trial. They are engaged in various criminal cases (murder, robbery, rape, etc.), civil cases (domestic violence, divorce, family law issues, business matters, personal injury, etc.), juvenile law related to protection of children, termination of parental rights, etc. and work at different stages of the process, including the out-of-court settings (lawyer's office, police station, prison, medical institutions) and during polygraph testing, psychiatric examination, etc.

Nowadays, there is a high interpreter demand in most developed countries, including the U.S. This demand is constantly growing. For instance, California's superior courts recorded over 4.4 million interpretations for the four-year study period (fiscal year $2014-2015$ through fiscal year 2017-2018). Criminal cases, though demonstrating the declining tendency, comprised around 75 percent of the total number of interpreter use with Spanish as by far the most interpreted language accounting for 91.36 percent of the overall interpreter volume. The top ten also include Vietnamese, American Sign Language, Mandarin, Cantonese, Korean, Punjabi, Russian, Arabic, and Farci. Declining in number were also juvenile interpretations $(474,750$ court cases) whereas interpretation in civil case type rose dramatically almost doubling from 35,213 interpretations in 2014-2015 fiscal year to 67,645 in 2017-2018 fiscal year (2020 Language Need and Interpreter Use Study). 
The figures of foreign-born individuals resided in US and speaking a foreign language at home is also impressive. In 2018 they accounted for 45 percent of population in California, 36 percent in Texas, 34 percent in New Mexico, 32 percent in New Jersey, 31 percent in New York and Nevada (each), 30 percent in Florida, 28 percent in Arizona and Hawaii (each) and 24 percent in Massachusetts (ibid).

That shows that courts cannot operate without interpreters' assistance. According to statistics, while $99 \%$ of youths appearing in juvenile court are quite fluent in English, their parents are often not. Thus, the Arkansas Administrative Office of the Courts has allocated a USD $0.34 \mathrm{~m}$ budget to hire interpreters (mostly freelance professionals) for court proceedings.

Dino (2018) argues that translation and interpreting was 2017's top emerging career in the United States, according to University of California, San Diego. This profession was listed as the 2017 US News and World Report's number one job in the Best Creative and Media Jobs category. Interpreters in courtrooms are in very high demand because of the increased cultural and linguistic diversity that is now the main reason why courts across different states face insufficient number of qualified interpreters, particularly in other than Spanish languages.

Court translators and interpreters are organized in professional associations, which perform a number of functions. Most important of them are running a register of qualified interpreters and translators available to courts, law enforcement agencies and other employers, certification of those engaged in these activities, sharing practices and offering courses of further education.

\subsection{Objectives, Materials, and Methodology}

The research aims to look at court interpreters' institutes in a number of English-speaking countries, namely the United States of America, Australia and Canada. The United Kingdom, as a European country is included in another research. Altogether they form parts of the wider topic of specifics of interpreter's engagement in criminal proceedings in a number of national jurisdictions.

The tasks set forth in this article is to study the activities of court interpreters' institutes, to look at their functions and output in providing language access services for those less fluent in the language of court proceedings.

The materials for this research include academic developments by both Russian and foreign authors, which form the theoretical basis of the work, and relevant information elicited from documents, regulations, acts, and rules of the countries mentioned above. Amount of internet sources is quite extensive; this allows to get relevant information firsthand and timely.

Theoretical and analytical methods, such as search, investigation, synthesis and analysis and processing of information have been applied to shape up the general concept and vision of the topic, while comparative and contrasting methods helped to estimate strengths and weaknesses of court interpreting services in different countries. Deductive reasoning contributed to the coherent and logical flow of the work and formulation of its main findings.

\section{INSTITUTE OF COURT INTERPRETERS IN THE UNITED STATES OF AMERICA}

In the United States, the rules for attracting interpreters to judicial proceedings are created by the Administrative Office of the United States Courts, which is the administrative wing of the US federal court system. It acts strictly in accordance with the rules regulating interpreting standards in the United states which were established in 1978 by the Court Interpreters Code 28, $\$ 1827$ and signed by President Carter (Gonzalez et al 1991). Since then, the Code has been amended and is now regulating this sphere of judicial activities quote comprehensively. According to this law the Director of Administration Office establishes the mandatory requirements for applicants seeking judicial interpreter's certification; also, he certifies interpreters based on the results of criterion-referenced performance examination. There is a constantly updated list of all certified and otherwise qualified interpreters from which the court can choose an interpreter for a particular case. The responsibility for providing translation services is borne by the court clerk or another court official designated by the chief judge. When no certified interpreter is reasonably available, as determined by the presiding judicial officer, the services of an otherwise competent interpreter can be utilized.

According to this legislation, Spanish interpreters who work in the federal courts should demonstrate their proficiency by passing a special certification exam. The Court Interpreters Code established the right for any person who participates in criminal proceedings to have a certified or otherwise qualified legal interpreter if their capabilities to understand and possible communication in the language of legal proceedings is not 
enough. These are situations when the person involved cannot fully and correctly assess the course of the court trial, and/or be aware of what is happening due to the language barrier.

There are also some certification requirements for court interpreters in certain states in the US. They started developing after adopting the Court Interpreters Code in different states at different times. For example, California began testing interpreters in 1979, followed by New Jersey in 1987, New Mexico in 1985 and New York in 1980. To pool resources for testing and training of judicial interpreters, a consortium of states was established by the National Center of State Courts in 1995 (Mikkelson, 1999).

The current Federal certification examinations program for interpreters, called (FCICE), was designed to implement the Federal Code on Judicial Interpreters. This federal program develops principles for evaluating the work of certified and otherwise qualified judicial interpreters in the US federal courts (Examinee Handbook of April 1, 2019).

The non-profit organization of National Association of Judiciary Interpreters and Translators (NAJIT) was charted under New York State laws and the Court Interpreters and Translators Association, Inc. (CITA) was set up in 1978. It got its present-day name a decade later. The Association took a major step towards creating links with academic institutions (universities) by forming the Society for the Study of Translation and Interpretation. The purpose of the Society was to promote court interpreter training, special test development, and research. One of its priorities was to develop a NAJIT certification exam, which gives the judicial interpreter profession more enhanced supervision over credentialing process. These professional organizations along with the wide network of universities are involved in continuous education through specialized courses of different length and purposes to annual conferences, symposia and on-line training.

Federal Court Interpreter Certification Examination to gain the status of a court interpreter in the USA consists of two parts: oral and written. They test the interpreting skills to accurately perform simultaneous as well as consecutive interpretation and sight translations as encountered in the federal courts. It is offered for Spanish/English testing only (Federal Court Interpreter Certification Examination).

In August 2000, Bill Clinton, then President of the United States of America, signed a decree number 13166 on "Improving Access to Services for Persons with Limited English Proficiency". It described the notion of a person who speaks English less than very well and specified it in detail (so called Limited English proficient LEP in short). According to this classification, all federal agencies that conducted their programs and activities should, within a reasonable time frame, take steps to ensure that all the persons referred to in the program (LEP) participate in any federal programs and activities.

In 2008 the Institute of Public Policy and Law, which deals with issues of justice and democracy or the socalled Brennan Center for Justice, published an eighty-eight-page workbook called "Access to language in state courts"; it asserted that about 25 million people may be classified as LEP - persons with limited English proficiency. That paper also stated that about 13 million people who are limited in English proficiency, lived in those states where the court did not require the presence of a judicial interpreter during the judicial process, whereas about six million people who speak English limitedly lived in those states where the courts provided low-qualified court interpreters with poor standards of services, and did not charge for their provision.

In 2010 the Attorney General of the United States of America issued an order for all heads of departments of the country, indicating the need for compliance and the duty to be guided by decree 13166 in their work. A similar reminder to all judges and administrators of the US Federal Courts was sent in 2010 by Tom Perez, Assistant Attorney General of the Department of Civil Rights at the Department of Justice. Those steps were taken to standardize the interpretation of the law, as well as to enforce decree 13166 everywhere, in order to implement access to English for all persons within the judicial system who for one reason or another were part of the program (LEP).

The professional competencies (knowledge, professional skills and abilities) required of a federal court interpreter in the United States are highly complex. Communication in courtroom proceedings is considered to be more demanding than communication in everyday life or in other settings. For instance, the parties involved often use specialized and legal terminology, formal and informal registers of speech, dialects and jargon; there can also be varieties in language and different nuances of meaning.

American court interpreters are divided into the following categories:

(a) Certified interpreters of Spanish, Navajo (local Indian) and Creole Haitian languages who passed the certification exam at the Administrative Office of the United States Federal Court in approved state certification programs for translation and interpretation. 
Certification programs were initially developed for Spanish, Navajo and Haitian Creole, as stated above. The examinations are quite complicated. For example, Spanish-English Federal Court Interpreter Certification Examination includes two stages. Prior to oral examination candidates have to take a written examination to be allowed to take the oral exam. It should be noted that oral exam has been developed to measure a candidate's ability to accurately perform both simultaneous and consecutive interpreting, as well as sight translation. The similar certification programs for the Navajo and Haitian Creole languages are no longer offered. It is necessary to highlight that in some other languages, court interpreters in the US can be of other two categories: professionally qualified and language skilled (website of the United States Court. Federal Court Interpreter Certification Examination).

b) Professionally qualified interpreters of other languages who have enough authentication and documentation, passed the test for seminar or conference interpreters in a language pair including English and one target language given by the U.S. Department of State, passed the interpreter test in English + a target language given by the United Nations, are presently a member of either AlIC (Association Internationale des Interprètes de Conférence) or TAALS (The American Association of Language Specialists). The membership qualification should be in English and the target language (ibid).

c) Language skilled/ad hoc interpreters who are sufficiently fluent in the language and proved before the judiciary their ability to successfully translate/interpret from/into another language (ibid).

Language Skilled or Ad Hoc court interpreters can assist the judicial authorities in the process of court proceedings and translate from English into the target language, and vice versa, however, they cannot be taken as professionally qualified interpreters. Such specialists can be qualified as interpreters with certain knowledge of the language. Professionally qualified and certified interpreters receive higher payments for their work than ad hoc interpreters.

US court interpreters are mostly freelancers and work under individual contracts. With a large load, courts employ a staff of interpreters, almost always with Spanish. Salaries of full-time interpreters vary from $\$ 30,000$ to $\$ 80,000$ per year. Oral and written court interpreters/translators can make more than $\$ 100,000$ per year, but usually with overtime (working over eight hours a day). Overtime does not apply to travel time. Their countdown begins after 17.30.

According to Federal Court Interpreters' official website (http://www.uscourts.gov/services-forms/federalcourt-interpreters), fees for Court Interpreters in 2018 were as follows:

Certified and Professionally Qualified Interpreters:

Full Day: $\$ 418$

Half Day: $\$ 226$

Overtime: $\$ 59$ per hour or part thereof.

Language Skilled (Non-Certified) Interpreters:

Full Day: $\$ 202$

Half Day: $\$ 111$

Overtime: $\$ 35$ per hour or part thereof.

If it is necessary to involve an interpreter with a rare language into the court process, the US Judicial Policy Manual, Volume $5, \S 420.40$, authorizes the courts to use the services of translation agencies. At the beginning of hearings, the interpreter takes an oath to interpret correctly (Vinnikov, 2013, p. 92).

The National Court Interpreter Database (NCID) was developed to register court interpreters and is used by the US federal courts to find necessary contact information when in need of contract court interpreting services. However, Judicial Councils of the United States Federal Courts are mostly cooperating with the interpreters listed with them. Judicial Councils conduct regular workshops for interpreter candidates, hold written exams and oral interviews in order to familiarize candidates with the state court system and the interpreter's role in a courtroom setting (Maryland Court Interpreter Program).

To be included into the NCID does not require any fees, however, certified and registered interpreters pay their annual renewal fee to the Judicial Councils of the United States Federal Courts; in California it comprises $\$ 100$ for the year of 2021 (website of California Courts. Court Interpreters program). If payments are not received by the due date, certification or registration status is revoked. 
Court Interpreters Program makes provision for continuous education of 40 hours for all certified court and registered interpreters and 30 court-related or other qualifying professional interpreting assignments every two-year period (CIMCE - Court Interpreter Minimum Continuing Education) (Compliance Requirements for California Certified Court and Registered Interpreters).

The COVID - 2019 pandemic seriously impeded the work of American courts; however, the judiciary system introduced many changes to the organization, management and services to meet the current challenges. Though the courts are operating with reduced capacity they are present both in normal sittings in a courtroom and remotely to efficiently administer justice. That means that trials with participants whose fluency in English is impaired need interpreting services.

\section{INSTITUTES OF COURT INTERPRETING IN AUSTRALIA AND CANADA}

Australia and Canada recognize court interpreting as a separate occupation and share many common requirements to practitioners working in this domain. Gradually forming the institute of court interpreters with identified autonomy, reliance on public sector financing and academically led, Australia began requiring a proficiency exam for court interpreters in 1978, Canada in the early 1980s.

In Australia, accredited interpreters are registered in a number of professional organizations. In this research we will only mention several of them:

1) National Association of Judiciary Interpreters and Translators (NAATI) with over 15,000 practitioners with credentials in more than 170 languages (website of NAATI). The Association assigns the following degrees of competency starting with January 2018: certified translator, certified advanced translator, and recognized practicing translator; certified provisional interpreter, certified provisional Auslan interpreter, certified provisional deaf interpreter, certified interpreter, certified specialist health interpreter, certified specialist legal interpreter, certified conference interpreter.

Interpreters' certification is conducted through testing the necessary knowledge, skills and abilities (KSAs) that have been scientifically verified and described. They include language competency, intercultural competency, research competency, technological competency, thematic competency, transfer competency, service provision competency and ethical competency.

The category of certified interpreters are practitioners whose competencies have been assessed and allow working in certain typical settings, and interpreting modes. Recognised practicing interpreter's category involve those working with emerging or low demand languages. For such practitioners NAATI only assesses language competency (English or Auslan), intercultural competency and ethical competency whereas other competencies are confirmed indirectly through evidence of work experience (ibid).

2) The Australian Institute of Interpreters and Translators (AUSIT) is the nationwide association with the emphasis on a continuing professional development (website of AUSIT). It does not certify candidates but arranges regular, and varied Professional Development Events such as workshops, webinars, and networking. Such events add to the knowledge of practitioners and provide points for NAATI recertification that takes place every three years.

AUSIT also runs a Board of Professional Conduct that deals with disputes, grievances, breaches of the AUSIT Code of Ethics and produces considered, evidence-based written opinions of various instances of professional practice that require examination and comment (ibid).

AUSIT closely cooperate with other national and international associations and organisations forming language services industry, among them are Australasian Association of Language Companies (AALC) representing the private sector in language service of Australia and New Zealand, International Association of Conference Interpreters (AIIC), International Association of Professional Translators and Interpreters (IAPTI), Western Australian Institute of Translators and Interpreters Inc. (WAITI) and some others.

It should be noted that Australian legislation provides for the use of only accredited and registered with NAATI interpreters to a minimum standard of NAATI Level 3. Less efficient Level 2 accredited interpreters may be accepted for a number of languages in the acceptable circumstances. In case when an accredited interpreter is not available a court may employ interpreter services at its discretion if it is appropriate in terms of costs and time of the interpreter en route. Previously, the court staff must ensure that the interpreter correctly understands his/her role, that there is no conflict of interest, and that he/she observes confidentiality. It is not allowed to deny the right to an interpreter due to the lack of funding. Unaccredited interpreters are most often employed in cases that need Aboriginal or emerging languages rendition. (website of Federal Circuit Court of Australia. Interpreter Policy). 
Judicial interpreters can also be engaged in public service interpreting in the police, immigration centers, governmental and healthcare departments. The challenges of this profession include their low social status, insufficient pay and lack of career growth.

In Canada, a certification exam for court interpreters was first developed by the Society of Translators and Interpreters of British Colombia (STIBC) in the early 1980s, and eventually the practice was spread throughout the entire country. It is now overseen by the Canadian Translators, Terminologists and Interpreters Council (CTTIC).

Accreditation of court interpreters in Canada is the prerogative of the Canadian Ministry of the Attorney General. It conducts examinations and severely selects interpreters for courtroom services. Ministry develops examination tasks, and updates testing materials in time. The exam for the accreditation includes sight translation of relevant materials from English into any other language and vice versa, consecutive translation of the witness's testimony from a foreign language into English, simultaneous interpreting of a dialogue from English into a foreign language, simultaneous interpreting of the monologue from English into a foreign language (Ministry of the Attorney General. The English Court Interpreting Test).

The existing requirements to the candidates for the status of judicial interpreter are very high: only those who have gained at least $70 \%$ in each section of the test are accredited (ibid).

In 1999 Canadian Ministry of Justice issued a manual on judicial interpretation, which contains legal, deontological, methodological and linguistic parts. The guide also included examination questions for candidates who wished to qualify as courtroom interpreters. As a result of strict selection, in 2013 there were only 73 accredited and 112 conditionally accredited court interpreters in Toronto, home to 1.4 million people who spoke neither English nor French at home. Of those, only two interpreters specialized in the Portuguese language, one in Italian and one in Mandarin dialect of the Chinese language. There were no interpreters from Korean, Turkish, Filipino, Khmer, Tamil, Punjab, and African languages. The practitioners were unhappy with the rates and claimed that the Ministry was trying to economize on quality specialists (Small 2011).

The latest information asserts that the Ministry of the Attorney General of Ontario offers court interpretation in over 80 spoken languages including sign language and Langue des signes du Québec (website of the Ministry of the Attorney general of Ontario). The Ministry Services Division runs the registry of approximately 700 accredited freelance court interpreters. However, judging by the current internet information concerning interpreting and translation business the need for quality practitioners is still high. The Job Outlook in BC (NOC 5125) predicts a rise in translators and interpreters' employment by 1,8 \% in the period of 2018-2023, and by $1,6 \%$ in the period of 2023-2028 (Translators and Interpreters. Skilled Immigrant InfoCentre).

The remuneration of court interpreters in Canada is not so generous as in the US. However, expenses of the state for fees, travel, etc. for more than two hundred interpreters of oral and written translations of more than sixty languages and dialects, accredited and non-accredited, who work with the Canadian Ministry of the Attorney General, amounts to $\$ 1$ million annually. Montreal, which is increasingly becoming multinational, provides the most work. Freelance court interpreters are paid $\$ 30$ per hour, or part thereof for guaranteed a three-hour minimum (Ministry of the Attorney General website)

Associations for translators and interpreters in Canada operate in strict National Standard of Canada Translation Services adopted in 2017 and National Standard Guide for Community Interpreting Services adopted in 2007.

\section{RESEARCH FINDINGS}

In all the countries reviewed, there is a variety of sworn, judicial, certified, accredited, and other categories of interpreters. However, the insufficient multiplicity and volatility of the nomenclature of the required languages in translating and interpreting does not satisfy all the needs of the national criminal court practice.

The criminal procedural laws of all countries under study allow involvement in the criminal proceedings of any person who speaks both the native language of a suspect/defendant and the language of the jurisdiction of the state in question. Criminal cases are the most consuming in terms of interpretation services whereas the non-criminal court cases form the ever-growing volume of interpretation and language access volume.

Since adoption of the U.S. Language Access Plan in 2015, interpreting serves are not only provided in mandated case types including felony, misdemeanor, infraction, traffic, juvenile (delinquency and dependency) and mental competency cases but are also available in all cases and case types upon request. The expansion of interpretations into civil case types reached 18.6 percent of total interpretations by the end 
of the most recent study period (2017-2018 financial year) (2020 Language Need and Interpreter Use Study). This trend is also traced in Australia and Canada where decisions on interpreter use are at court discretion.

The costs for the services of judicial and police interpreters reach enormous proportions. Significance of costs for judicial and police needs for interpreters compels the authorities to seek ways to save money thus reducing the quality of court proceedings with an interpreter.

Challenging is also the issue of organization and management within the translation and interpreting industry. The state judicial and law-enforcement systems cannot do without language assistance at the time of growing rates of criminal offences involving suspects who do not comprehend or speak the language of jurisdiction. The huge army of translators/interpreters engaged in legal language service vary from the judicial crime linguists, on the one hand, and unmanageable number of jurors, accredited or non-accredited, certified and non-certified independent interpreters working on a freelance basis. Even less manageable are the masses of non-professional interpreters, who represent various ethnic groups. They are increasingly required to be involved in criminal trials instead of qualified specialists.

It is especially true with the rare languages including Asian and African due to extensive migration movements. Participation of sworn, accredited, certified, and licensed interpreters in the trial process is not legally obliged. There is a conflict between quality interpreting and saving money policy, which results in the choice between qualified professionals from commercial, judicial and translation agencies, and independent interpreters of various qualifications.

Despite evident challenges, in the whole, the existing organization of justice administration with interpreter's participation is quite effective.

Based on the analysis of this research we can conclude that court interpreting in the countries under study forms an independent sphere of professional activity with full-fledged systems of public service interpretation provision. They have developed rather efficient institutes of court interpreting meeting the present-day social needs. Regulated by national legislations they perform their mission in providing equal access to justice and realization of human rights. They are supported by academic studies outlining the scope of specialized knowledge and skills and are governed by standards of performance and behaviour to be complied. The court interpreting institutes possess mechanisms for testing, certifying and monitoring conformance to standards and involve a great number of stakeholders including state, public and professional associations and organisations to create a shared environment.

\section{ACKNOWLEDGEMENT}

The publication has been prepared within the RUDN University 5-100 project.

\section{REFERENCE LIST}

Compliance Requirements for California Certified Court and Registered Interpreters. Judicial Council of California. Court Interpreters Program. 2019. URL: https://www.courts.ca.gov/documents/CIPCompliance-Requirements.pdf

Compliance Requirements for California Certified Court and Registered Interpreters. Judicial Council of California. Court Interpreters program. URL: https://www.courts.ca.gov/documents/CIP-ComplianceRequirements.pdf

Dino D. (2018). Demand in the US for Legal and Healthcare Interpreters Gets Increasing Media Attention. Slator. January 17, 2018. URL: https://slator.com/demand-drivers/demand-in-the-us-for-legal-andhealthcare-interpreters-gets-increasing-media-attention/

Fair Trials Europe. Roadmap Practitioner Tools: Interpretation and Translation Directive. March 2015. URL: https://www.fairtrials.org/wp-content/uploads/Language-Rights-Toolkit-FINAL.pdf

Federal Court Interpreters (The USA). URL: http://www.uscourts.gov/services-forms/federal-courtinterpreters

Federal Court Interpreter Certification Examination. Unites States Court. URL: https://www.uscourts.gov/services-forms/federal-court-interpreters/federal-court-interpreter- 


\section{certification-examination}

Federal Court Interpreter Certification Examination. Examinee Handbook. Administrative Office of the United States Courts. Las Revised April 1, 2019. URL: https://www.prometric.com/sites/default/files/201909/fcice examineehandbook.pdf

Gonzalez R., Vasquez V. and Mikkelson H. (1991). Fundamentals of Court Interpretation: Theory, Policy and Practice. Durham, NC: Carolina Academic Press.

Maryland Court Interpreter Program. URL: https://mdcourts.gov/interpreter/workshop

Mikkelson H. (1999). Court Interpreting at a Crossroads. The National Association of Judiciary Interpreters and Translators Annual Conference (NAJIT), Washington.

Ozolins U. (2010). Factors that Determine Provision of PSI: Comparative Perspectives on Government Motivation and Language Service Implementation. The Journal of Specialised Translation, Issue 14.

Small P. (2011). Court Interpreter Shortage Nears Crises. Toronto Star. URL: https://www.thestar.com/news/crime/2011/01/28/court interpreter shortage nears crisis.html

Translators and Interpreters. Skilled Immigrant InfoCentre. URL: https://pwp.vpl.ca/siic/guides/translatorsinterpreters/

2020 Language Need and Interpreter Use Study of California https://www.courts.ca.gov/documents/2020Language-Need-and-Interpreter-Use-Study-Report-to-the-Legislature.pdf

Vinnikov A.V. (2013). On Global Laws of Police and Judicial Interpreting. Eurasian Advocacy, 1 (2).

Website of the Australian Institute of Interpreters and Translators (AUSIT). URL: https://ausit.org/about-uS/ ).

Website of Federal Circuit Court of Australia. Interpreter Policy. URL:

http://www.federalcircuitcourt.gov.au/wps/wcm/connect/fccweb/about/policies-andprocedures/interpreters

Website of the National Association of Judiciary Interpreters and Translators (NAATI). URL: https://www.naati.com.au/

Website of the Canadian Ministry of the Attorney General https://www.attorneygeneral.jus.gov.on.ca/english/courts/interpreters/apply.php

Website of the Canadian Ministry of the Attorney General. Court interpreters. https://find.gov.on.ca/?searchType $=$ simple\&owner $=$ mag\&url=\&collection=\&offset $=0$ \&lang=en\&type $=A$ NY\&q=court+interpreters\&search. $x=12 \&$ search. $y=9$

Website of the Canadian Ministry of the Attorney General. The English Court Interpreting Test. URL: https://www.attorneygeneral.jus.gov.on.ca/english/courts/interpreters/english test/

Website of Federal Circuit Court of Australia. Interpreter Policy http://www.federalcircuitcourt.gov.au/wps/wcm/connect/fccweb/about/policies-andprocedures/interpreters

Website of the United States Court. Federal Court Interpreter Certification Examination. URL: https://www.uscourts.gov/services-forms/federal-court-interpreters/federal-court-interpretercertification-examination 